\title{
Functional Characteristics of Marshmallow with Kinang (Chew of Betel) Extract Addition
}

\author{
Budi Santoso ${ }^{1}$, Endang Verawati ${ }^{1}$, Tri Wardani Widowati ${ }^{1}$, Siti Rusdiana Puspa Dewi ${ }^{1}$, Rindit Pambayun" \\ Postgraduate School Program, Faculty of Agriculture, Sriwijaya University, Palembang, South Sumatra, Indonesia 30152 \\ *Corresponding author: rpambayun@yahoo.com
}

Received October 15, 2018; Revised November 17, 2018; Accepted January 04, 2019

\begin{abstract}
The research objective was to determine functional characteristics of marshmallow with kinang (chew of betel) extract addition which consisted of 10 treatment levels: E1 (10\%), E2 (20\%), E3 (30\%), E4 (40\%), E5 (50 \%), E6 (60 \%), E7 (70 \%), E8 (80 \%), E9 (90 \%) and E10 (100\%) dissolved in $100 \mathrm{~mL}$ water used for gelatin soaking and 3 best treatments will be taken later. Determination of the best treatment was decided by organoleptic analysis based on the panelist preference. The three best treatments based on panelist preference were E4 (marshmallow $+40 \%$ kinang extract), E6 (marshmallow $+60 \%$ kinang extract) and E8 (marshmallow $+80 \%$ kinang extract). The testing conducted in the reserach were antibacterial analysis, antioxidant analysis and anti dental caries analysis, respectively. The best treatment was E8 (marshmallow $+80 \%$ kinang extract) having antibacterial activity of $2.15 \mathrm{~mm}$, antioxidant activity of $2.78 \mathrm{mg} / \mathrm{ml}$ and dental caries value of 4.0 and caries inhibition percentage of $83 \%$, respectively.
\end{abstract}

Keywords: chew of betel extract, marshmallow, functional, antibacteria, antioxidant

Cite This Article: Budi Santoso, Endang Verawati, Tri Wardani Widowati, Siti Rusdiana Puspa Dewi, and Rindit Pambayun "Functional Characteristics of Marshmallow with Kinang (Chew of Betel) Extract Addition." Journal of Food and Nutrition Research, vol. 7, no. 1 (2019): 1-5. doi: 10.12691/jfnr-7-1-1.

\section{Introduction}

Kinang (chew of betel) is a mixture of ingredients such as betel leaf, areca nut, lime and gambier used for betel chewing activity. The habit of betel chewing had been done since long time ago in Asia regions [4]. Betel chewing activity in Indonesia culture usually can be seen during marriage ceremony and most society members believe that betel chewing activity can strengthen teeth and prevent caries occurrence. According to [15], the longer the panelists conduct betel chewing activity, the lesser the caries occurrence.

Ingredients mixture for betel chewing activity have different benefits. For instance, gambier has benefit as bacterial growth inhibitor of Streptococcus mutans and antioxidant [15], due to its catechin content with magnitude of 7 to $33 \%$ [7]. Areca nut has benefits as antibacteria and antioxidant [8] because it has tannin content with magnitude of $15 \%$ [6]. Betel leaf produces specific aroma because it contains essential oil with magnitude of $4,5 \%$. Betel lime has capability to change acid environment into alkali (bases) environment [2].

The main ingredients in chew of betel formulation are gambier and areca nut that have benefit as antibacteria. Several studies had been conducted in conjunction with gambier as antibacteria. Pambayun et al (2008) had extracted catechin from gambier (Uncaria gambir Roxb) in order to observe sensitivity of Gram positive bacteria [15]. Pambayun, et al (2007) had stuided phenol content and antibacterial characteristics from several gambier products extraction (Uncaria gambir Roxb) [14]. Several studies had been conducted in conjunction with areca nut as antibacteria. Ryan (2015) had studied selenium from seeds and roots of areca nut (Areca catechu 1.) which fermented with consortium of Acetobacter Saccharomyces as the antiseptic for mouthwash [19].

Antibacterial content of gambier and areca nut are capable to inhibit teeth blighter bacteria, i.e. Streptococcus mutans, that can produce teeth caries [13]. Teeth caries is infectional disease that damage teeth structure (enamel) resulting in cavity of teeth [18]. Based on the previous statement, betel chewing activity has beneficial effect on teeth health, but its main drawbacks are impractical and capable to produce environmental pollution. This problem can be solved by producing functional food product, marshmallow added with chew of betel extract. Functional food is fresh or processed food that provides health benefit. Marshmallow is kind of soft candy made from mixture of sugar, glucose syrup, gelatin and flavoring ingredient [12]. Marshmallow has soft texture, can be bitten and not sticky in teeth when chewed, but it is easily melt in mouth. These characteristics are used as the consideration in producing of marshmallow product added with kinang extract.

\section{Materials and Methods}

\subsection{Production of marshmallow}

Production of marshmallow can be described as follows: 
a. Batter 1: gelatin of $30 \mathrm{~g}$ is soaked with water at ratio of water and chew of betel extract in accordance to the treatment with total volume of $100 \mathrm{~mL}$ for 10 minutes.

b. Batter 2: $30 \mathrm{~mL}$ of sugar syrup and $150 \mathrm{~g}$ of granulated sugar are added with water up to $100 \mathrm{~mL}$.

c. Batter 2 is heated for \pm 7 minutes at temperature of $105^{\circ} \mathrm{C}$.

d. Mixing of batter 1 and batter 2 by using mixer at speed 5 until homogenous for 10 minutes.

e. Homogenous batter is put into moulding and it is left over for \pm 4 jam.

f. Cutting of marshmallow with dimension of $2 \times 2$ $\mathrm{cm}$.

g. Marshmallow is sprinkled with fine granulated sugar and maizena flour $(1: 1)$

\subsection{Organoleptic Test}

Evaluation for aroma, texture, color, and taste of marshmallow was done organoleptically by using hedonic test. Testing was done to 30 somewhat trained panelists. Sampel was put on plate which is randomly given 3 digits code. Panelists were asked to give total preference assesment in term of color, taste, aroma, and texture by giving scores in 1-6 scale $(1=$ highly dislike, $2=$ very dislike, $3=$ dislike, $4=$ like, $5=$ very like, $6=$ highly like). Results of organoleptical test were analyzed by using non-parametric statistics with Friedman-Conover test.

\subsection{Test of Antibacterial Activity [5]}

Bacterium of Streptococus mutans was previously rejuvenated by taking bacterial inoculum on agar miring with magnitude of 1 Ose, put it into test tube containing nutrient broth of $9 \mathrm{~mL}$ and incubated for 24 hours at temperature of $37^{\circ} \mathrm{C}$. Soft media production with ratio of $1.3 \mathrm{~g}$ nutrien broth and $1 \mathrm{~g}$ bacteriological agar was then added with $100 \mathrm{~mL}$ aquadest and heated at temperature of $100^{\circ} \mathrm{C}$. Hard media production with ratio of $1.3 \mathrm{~g}$ nutrien broth and $1.5 \mathrm{~g}$ bacteriological agar was then added with 100 $\mathrm{mL}$ aquadest and heated at temperature of $100^{\circ} \mathrm{C}$.

Soft media, hard media and equipments used for innoculation were sterilized at temperature of $121^{\circ} \mathrm{C}$ for 15 minutes. Equipments used for bacteria implantationis put within laminar flow. Soft media preparation, addition of $0.1 \mathrm{~mL}$ Streptococus mutans bacterium at concentration of $10^{9} \mathrm{sel} / \mathrm{mL}$ was put into soft media and followed by pouring into petri dish. After cold, $15 \mathrm{~mL}$ hard media was poured into petri dish and was awaited until harden. Well is made with $6 \mathrm{~mm}$ in diameter, $4 \mathrm{~mm}$ in depth and added kinang extract of $5 \mu$ l. Petri dish was subsequently incubated within incubator at temperature of $37^{\circ} \mathrm{C}$ for 24 hours. Observation of antibacterial activity was shown by area of clear zone diameter developed in surrounding of kinang extract.

\subsection{Antioxidant Analysis}

Antioxidant activity was determined by using DPPH method as follows:

a. Sample of $1 \mathrm{~mL}$ was taken and put into test tube;

b. Methanol of $9 \mathrm{ml}$ was added into test tube containing sample and the mixture solution was vortexed; c. The dilution sample was taken with magnitudes of 1 $\mathrm{mL}, 2 \mathrm{~mL}, 3 \mathrm{~mL}, 4 \mathrm{~mL}$ and $5 \mathrm{~mL}$ followed by addition of methanol solution;

d. Sample of $2 \mathrm{~mL}$ was taken according to its dilution;

e. The dilution sample is added with $2 \mathrm{ml}$ of DPPH solution;

f. Sample was vortexed until homogenous;

g. Sampel was incubated at temperature of $37^{\circ} \mathrm{C}$ for 30 minutes;

h. Absorbancy of sample was determined by using spectrophotometer at $\lambda=517 \mathrm{~nm}$;

Percent of inhibition $(\%)=\frac{A_{0}-A_{s}}{A_{0}} \times 100 \%$

where:

$\mathrm{A}_{0}$ : Results of spectrophotometer at 0 minute.

$A_{S}$ : Results of spectrophotometer at 30 minutes.

i. After inhibition percentage value obtained, $\mathrm{IC}_{50}$ value could be calculated through straight line equation which relate dilutionconcentration and inhibition percentage. $\mathrm{IC}_{50}$ value was obtained from $\mathrm{X}$ value in the straightlineequation with $\mathrm{Y}$ value of 50. Straight line equation with dilutionconcentration as an axis andinhibition percentage as an ordinate is given in the following equation:

$$
y=a x+b .
$$

\subsection{Test of Teeth Anticaries}

The test for additional effect of kinang (chew of betel) formulation in marshmallow on teeth anticaries was done with in vivo method according [3]. Preparation of Exprimental Materials.

Kinang extract marsmallowis used according to specifid treatments. Samples in this research were white mice of Wistar strain (Rattus norvegicus L.). Inclusion criteria are male white mice, age in the range of 10 to 12 weeks, weight in the range of 100 to 150 grams and in healthy condition. Exclusion criteria are mice in physical and mentally disabilities condition. Sample numbers are 12 mice according to treatment. Marshmallow is given to mice by mixing samples into pellete with size of $1: 1$ ( $30 \mathrm{~g}: 30 \mathrm{~g}$ ) per day and tap water is also given to mice.

\section{a. Preparation of Experimental Animal}

Preparation of experimental animal is started with aclimatization. Aclimatization is adaptation process to the change of environmental condition. Mice are aclimatitated within research room for \pm 1 week at room's temperature. Mice are put into 12 square cages made of plastics and wire. Each cage contains 1 mouse.

\section{b. Innoculation of Sterptoccocus mutans}

Sterptoccocus mutansis prepared with Colony Forming Unit (CFU) of $10^{9}$ cells $/ \mathrm{mL}$. After aclimatization phase, Sterptoccocus mutans with magnitude of $0.2 \mathrm{ml}$ is given orally to mouse's mouth by using pipette for three days. This treatment taken place for four months.

\section{c. Euthanasia, preservation, jaw staining and sectioning}

After 4 months, mice are given euthanasia treatment by putting them into airtight box and chloroform is given to mice for 5 minutes. Subsequently, two jaws of mice are taken by using scalpel and blade. These jaws are cleaned with 1-2 \% ammonium hydroxide solution for about 30 
minutes. Preservation is done by soaking the jaws in formalin for 24 hours in order to prevent decaying. Staining phase is done by soaking jaws in $1 \%$ methylene blue solution for about 4 hours. After the end of staining phase, jaws are cleaned and dried followed by sectioning of mice jaws by using carborundum disc attached on straight handpiece.

\section{d. Caries Evaluation on Mice}

Caries evaluation on 12 molar teeth of white mice of Wistar strain is done by using Keyes method. This method evaluates caries by observing caries lesi based on its depth with the aid of USB Digital Microscopeat 300 magnification from smoothsurface (buccal, lingual) and sulkal surface (pit and fisur). Keyes had classified caries depth into 4 parts as follows:

1) Email (E): Lesions of caries only reach email area.

2) Slight Dentinal (Ds): Lesions of caries already reach dentino email junction (DEJ) or limited dentin.

3) Moderate Dentinal (Dm): Lesions of caries already reach $1 / 4$ to $3 / 4$ dentin depth.

4) Extensive Dentinal (Dx): Lesions of caries already reach more than $3 / 4$ of dentin depth.

Caries numbers occurred in each of mouse teeth are noted according to caries depth.

\section{Results}

\subsection{Organoleptical Test}

\subsubsection{Color}

Data analysis of hedonic test in term of marshmallow color showed that critical value was less than F-table value so that no further test was conducted. Organoleptical test results for marshmallow color of kinang extract showed that the highest preference level score was 4.3 (like) and the lowest one was 3.0 (dislike).

\subsubsection{Taste}

Data analysis of hedonic test in term of marshmallow taste showed that critical value was less than F-table value so that no further test was conducted. Organoleptical test results for marshmallow taste were in the range of 4.2 (like) to 3.4 (dislike).

\subsubsection{Aroma}

Data analysis of hedonic test in term of marshmallow aroma showed that critical value was higher than F-table value so that further test was conducted. Panelists assessment to marshmallow aroma were in the range of 3.92 to 3.52. Marshmallow aroma with the highest score was found on E1 treatment (marshmallow with $10 \%$ chew of betel extract) and the lowest one was found on E10 (marshmallow with 100\% chew of betel extract). Results of Friedman-Conover test can be seen in Table 1.

\subsubsection{Texture}

Data analysis of hedonic test in term of marshmallow texture showed that critical value was higher than F-table value so that further test was conducted. Results of Friedman-Conover test can be seen in Table 2 .
Table 1. Results of Friedman-Conover test for marshmallow aroma

\begin{tabular}{ccc}
\hline Treatments & Rank numbers & $\mathrm{X}=36$ \\
\hline E10 $(100 \%$ boce $)$ & 627.6 & $\mathrm{a}$ \\
E6 $(90 \%$ boce $)$ & 760.3 & $\mathrm{~b}$ \\
E8 $(80 \%$ boce $)$ & 769.5 & $\mathrm{~b}$ \\
E7 $(70 \%$ boce $)$ & 788.3 & $\mathrm{~b}$ \\
E9 $(60 \%$ boce $)$ & 912.8 & $\mathrm{c}$ \\
E4 $(50 \%$ boce $)$ & 996.5 & $\mathrm{~d}$ \\
E5 $(40 \%$ boce $)$ & 105.5 & $\mathrm{e}$ \\
E3 $(30 \%$ boce $)$ & $1,055.5$ & $\mathrm{e}$ \\
E2 $(20 \%$ boce $)$ & $1,097.3$ & $\mathrm{e}$ \\
E1 $(10 \%$ boce $)$ & $1,164.5$ & $\mathrm{f}$ \\
\hline
\end{tabular}

*) boce $=$ kinang extract

Remarks: Numbers followed by the same letter in the same column are not significantly different.

Table 2. Results of Friedman-Conover test for marshmallow texture

\begin{tabular}{ccc}
\hline Treatments & $\begin{array}{c}\text { Rank } \\
\text { numbers }\end{array}$ & $\mathrm{X}=11,55$ \\
\hline E10 $(100 \%$ boce $)$ & 102 & $\mathrm{a}$ \\
E 6 $(90 \%$ boce $)$ & 668 & $\mathrm{~b}$ \\
E 8 $(80 \%$ boce $)$ & 794.3 & $\mathrm{c}$ \\
E 7 $(70 \%$ boce $)$ & 842.8 & $\mathrm{~d}$ \\
E 9 $(60 \%$ boce $)$ & 872 & $\mathrm{e}$ \\
E 4 $(50 \%$ boce $)$ & 1,001 & $\mathrm{f}$ \\
E 5 $(40 \%$ boce $)$ & 1,030 & $\mathrm{~g}$ \\
E 3 $(30 \%$ boce $)$ & 1,119 & $\mathrm{~h}$ \\
E 2 $(20 \%$ boce $)$ & 1,166 & $\mathrm{i}$ \\
E 1 $(10 \%$ boce $)$ & 1,193 & $\mathrm{j}$ \\
\hline
\end{tabular}

Remarks: Numbers followed by the same letter in the same column are not significantly different/

\subsection{Analysis of Antibacterial Activity}

Results of antibacterial activity measurement can be seen in Figure 1.

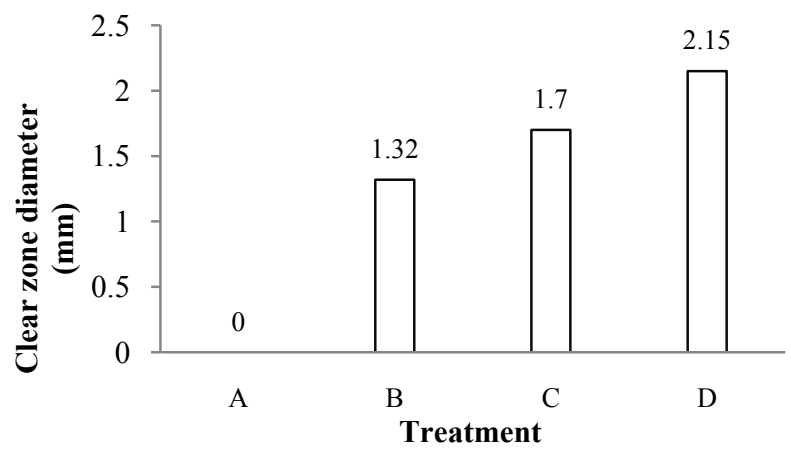

Remarks:

A: marshmallow with $0 \%$ boce $\quad$ C: marshmallow with $60 \%$ boce B:marshmallow with $40 \%$ boce $\quad$ D: marshmallow with $80 \%$ boce

Figure 1. Antibacterial activity test

\subsection{Antioxidant Analysis}

Figure 2 showed that the higher the addition of kinang extract to marshmallow, the lower the $\mathrm{IC}_{50}$ value which means high antioxidant activity. The strength of antioxidant activity on marshmallow can be classified as very weak because it had $\mathrm{IC}_{50}$ values in the range of $81.05 \mathrm{mg} / \mathrm{ml}$ to $2.78 \mathrm{mg} / \mathrm{ml}$. Results of antioxidant test can be seen in Figure 2. 


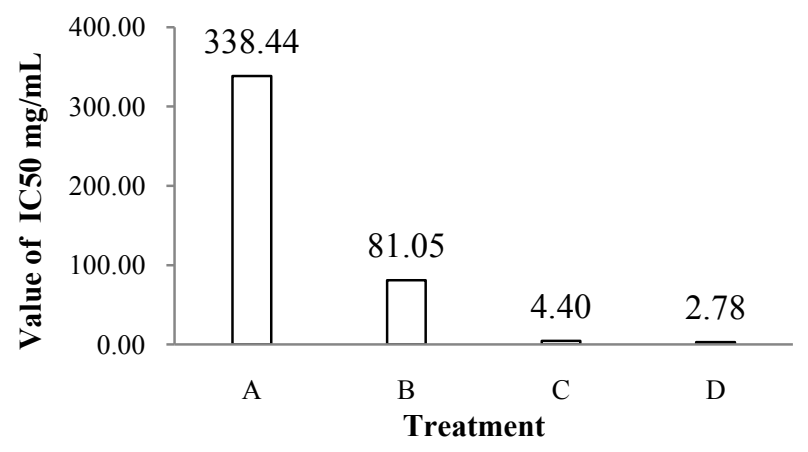

Remarks:

A : marshmallow with $0 \%$ boce $\quad$ C: marshmallow with $60 \%$ boce $\mathrm{B}$ :marshmallow with $40 \%$ boce $\quad$ D : marshmallow with $80 \%$ boce

Figure 2. Analysis of antioxidant activity

\subsection{Test of Teeth Anticaries}

The objective of teeth anti-caries test is to determine marshmallow capability as teeth anti-caries. Results of teeth anti-caries test can be seen in Figure 3.

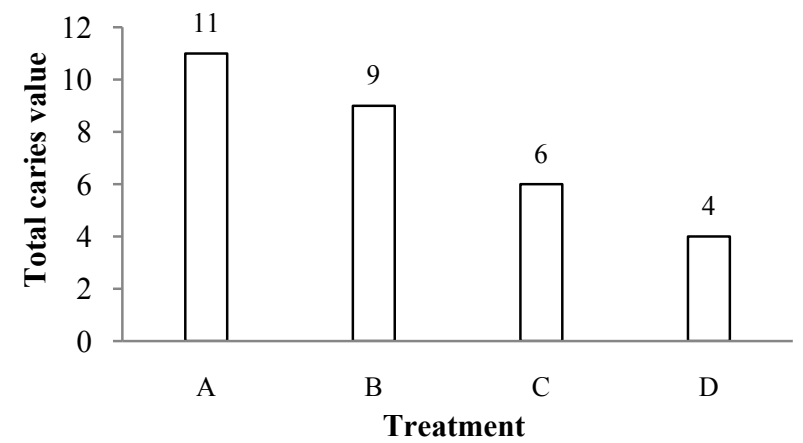

Remarks:

A: marshmallow with $0 \%$ boce $\quad$ C: marshmallow with $60 \%$ boce B:marshmallow with $40 \%$ boce $\quad$ D: marshmallow with $80 \%$ boce

Figure 3. Test of teeth caries value in teeth enamel

The percentage of caries development prevention can be seen in Figure 4.

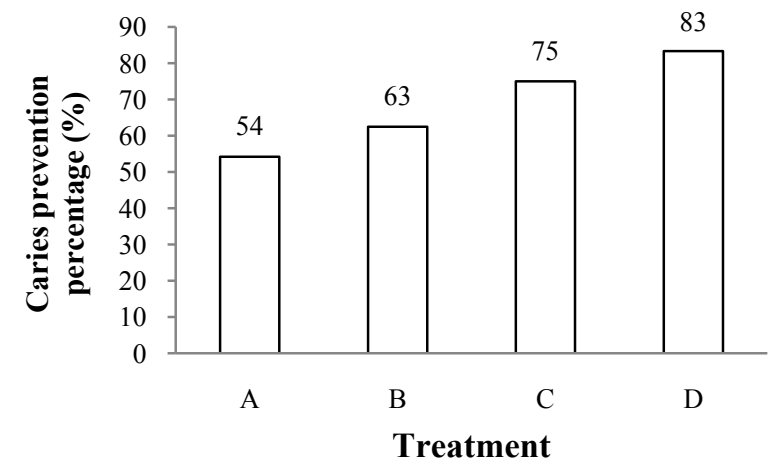

Figure 4. Percentage of caries development prevention

\section{Discussion}

Organoleptical test resul basats of marshmallow with addition of chew of betel extract had effect on organoleptical values of color, taste, aroma and texture. Higher addition kinang extract results in lower preference of color because the produced marshmallow had brownish red color. The brownish red color in kinang extract is affected by availability of gambier and areca nut which contain catechin and tannin. Kinang processing involved addition of betel lime that has $\mathrm{pH}$ higher than 7.0 or in bases condition [11]. Atechin has golden yellow color and it can be degraded at netral or basa condition into tearubigin compound [1]. Tearubigin is compound that produce brownish red color [22]. Catehin and tannin also have effect on taste. Catechin and tannincom pounds can produce bitter and splinting tastes. Marshmallow produced in this research had specific taste due to addition of betel leaves in kinang. Distinctive sharp aroma of betel leaf is due to cavicol and betlephenol content in essential oil [20]. The addition of kinang extract on marshmallow production had effect on texture, i.e. the higher the addition results in more supple texture of marshmallow. Textural value of marshmallow can be due to ingredients formulation and production method. The low quantity of air trapped in mixing process results in hard texture of marshmallow.

Marshmallow with kinang extract addition can affect antibacterial activity and antioxidant activity. Catechin compound in gambier and tannin compound in areca nut are capable to inhibit Streptococus mutans bacterium (Figure 2). According to the studies from $[1,14]$ catechin compound in gambier and tannin compound in areca nut are capable to inhibit Gram-positive bacteria. The inhibition mechanisms of Gram-positive bacteria is occurred through bonding between catechin compound in gambier and tannin compound in areca nut with peptide units within peptidoglycan component of cells wall.

Peptidoglycan is componentof bacteria cell wall that capable to shape strong bacteria cell wall in which bacteria capable to survive at different osmosis pressure condition than that of within cells. The formation of peptidoglycan is dibantu by transpeptidase enzyme [10]. Transpeptidase enzyme has function to combine one unit of peptidoglycan with other unit of peptidoglycan resulting in strong bacteria cell wall. Catechin and tanin are capable to inhibit activity of transpeptidase enzyme [9] that cause bacteria cell wall become weak which disrupt integrity of bacteria cell wall and subsequently cause leakage of bacteria cell wall. Leakage of bacteria cell wall causes disturbance of metabolisms process resulting in death of cells.

Catechinand tanin have capability as antioxidant (Figure 2) because both compounds are polyphenol group that have more than one hydroxil group.The compound which contain hydroxil group $(-\mathrm{OH})$ will donate hydrogen atom $(\mathrm{H})$ to radical compound or will change radical compound into more stable compound [15].

The F5 treatment ( $8 \mathrm{~g}$ betel leaf, $2 \mathrm{~g}$ betel lime, $3.5 \mathrm{~g}$ areca nut, $2.5 \mathrm{~g}$ gambier) with the highest antioxidant value of 2.78 had weak antioxidant intensity. According to [18], antioxidant intensities can be classified according to $\mathrm{IC}_{50}$ values as follows: very strong $\left(\mathrm{IC}_{50}<0.05 \mathrm{mg} / \mathrm{ml}\right)$, strong $\left(\mathrm{IC}_{50}=0.050,1 \mathrm{mg} / \mathrm{ml}\right)$, medium $\left(\mathrm{IC}_{50}\right.$ in therange of 0.1 to $0.25 \mathrm{mg} / \mathrm{ml}$ ) and weak $\left(\mathrm{IC}_{50}\right.$ in therange of 0.25 to $0.50 \mathrm{mg} / \mathrm{ml}$ ).

Teeth anticaries test showed that the higher the kinang extract addition on marshmallow, the lower the total caries value on mouse's teeth (Figure 3). Caries is developed at enamel part of experimental mice teeth. Caries is 
previously developed at enamel because enamel has higher chewing load than that of dentin part. Caries can be developed because Streptoccocus mutans bacteria which exist in mouth are capable to ferment glucose into lactate acids, resulting in decrease of $\mathrm{pH}$ in mouth and subsequently produce demineralization of teeth enamel.

Demineralization is precipitation process of mineral ions from teeth enamel due to reaction of hidroxyapatite (HA) mineral which consisted of $\mathrm{Ca}_{10}\left(\mathrm{PO}_{4}\right)_{6}(\mathrm{OH})_{2}$. Ion of $\mathrm{H}+$ at acid condition reacts with phosphate group and produce hydrogen phosphate $\left(\mathrm{HPO}_{4}{ }^{2-}\right)$, whereas $\mathrm{H}+$ ions at the same time experience buffering which cause in balance condition of hidroxyapatite mineral followed by dissolution of hidroxyapatite mineral.

Marshmallow with kinang extract addition had effect as inhibitor anti caries because it contains catechin and tanin from kinang extract. Catechin and tanin had effect as inhibitor of teeth caries because catechin compound from gambier and tanin compound from areca nut are effective in inhibiting of Streptoccocus mutans bacteria [14] (Figure 4).

The results showed that marshmallow with kinang extract addition can not prevent the caries occurrence, but only capable to inhibit the caries occurrence with the lowest value found on F5 treatment ( $8 \mathrm{~g}$ betel leaf, $2 \mathrm{~g}$ betel lime, $3.5 \mathrm{~g}$ areca nut, $2.5 \mathrm{~g}$ gambier).

\section{Conclusion}

Organoleptical test was conducted on marshmallow with kinang extract addition at concentrations of $40 \%$, $60 \%$ and $80 \%$. The best marshmallow was found on D treament (marshmallow with $80 \%$ kinang extract) having antibacterial activity of $2.15 \mathrm{~mm}$ and antioxidant activity of $2.78 \mathrm{mg} / \mathrm{ml}$, respectively. Marshmallow with kinang extract had brownish red color. Anticaries activity test on marshmallow showed that D treatment (marshmallow with $80 \%$ kinang extract) had high inhibition power with caries value of 4 and caries inhibition percentage of $83 \%$, respectively.

\section{Acknowledgements}

The writer would like to acknowledge to The Research and Community Extension Service Council (LP2M) of Sriwijaya University, Minister of Research and Technology of Higher Education that had provided research grant funding for 2017 fiscal year with Contract No. 1011/ UN9.3.1/PP/2017 and Prof. Dr. Ir. Rindit Pambayun, M.P. as Chief Researcherfor their financial support in this research.

\section{References}

[1] Anggraini. T., Febrianti. F., Aisman and Ismanto, S.D. 2016 Black Tea With Averrhoa bilimbiL Extract: A Healthy Beverage. J. Agric. Scie. Proc, 9, 241-252.
[2] Dwi, W.A. F. 2007. Aspesification Implementation on Upper Front Teeth Fractures Due to Trauma. Indonesian Journal of Dentistry, 14(3), 199-203.

[3] Everett, Henry, M., Reynolds.,Eggertsson., Sullivan., Kantmann., Mier, M., Warrick, J andStookey, G. 2002. Dental Fluorosis: Variability among Different Inbred Mouse Strains. Journal of Dental Research, 81(11), 794-798.

[4] Gandhi, G., Kaur, R. and Sharma, S. 2005. Chewing pan masala and betel quid-fashionable attributes and cancer menaces. Journal of Human Ecology, 17(3), 161-6.

[5] Goyal, P., Chauhan, A.and Kaushik. 2009. Laboratory Evaluation of Crude Extracts of Cinnamomum tamala for Potential Antibacterial Activity. J. Elec. Bio, 5(4), 75-79.

[6] Harnowo, I. and Yunianta. 2015. The Addition of Areca Nut Seed Extract and Citric Acid on Physical, Chemical and Organoleptical Characteristics of Sweet Star Fruit Juice. Journal of Food and Agroindustry, 3 (3), 1241-1251.

[7] Isnawati, A., Raini, M., Sampurn, O., Mutiatikum., Widowati, L. and Gitawati, R. 2012. Characterization of Three Types of Gambier Extract (Uncaria Gambir Roxb) from West Sumatra. Journal and Bulletin of Health Research, 40 (4), 201-208.

[8] Kim, J.M., Marshal, M.R and Wei, C.L. 1995. Antibacterial Activity of Some Essential Components Against Five Food Brone Pathogenes. J. Agric, and Food Chem, 43, 2839-2845

[9] Mamonto, S., Runtuwene and Wehantouw, F. 2014. Antioxidant Activity of Yaki Areca Nut Seed Skin (Areca vestiaria g.) Extracted by Using Sokhlet Method. Scientific Journal of Pharmacy. UNSRATISSN 2302 - 2493, 3 (3), 263-272.

[10] Morelli. C., Calvio. C., Biagiotti. M and Speranza, G. 2014. $\mathrm{pH}$-Dependent Hydrolase, Glutaminase, Transpeptidase And Autotranspeptidase Activities Of Bacillus SubtilisGlutamyltransferase. Journal FEBS. 281 : 232-245

[11] Musdholifah and Zubaidah. E. 2016. Antioxidant Activity Study of Kefir Tea of Sirsak Leave from Several Trademarks in Market. Journal of Food and Agroindustry, 4(1), 29-39.

[12] Nikita, A., Herla, R. andRona, N. 2014. The Effect of Red Guavaand Lemon Ratio and Gelatin Concentration onMarshmallow Quality of Red Guava. Journal of Food Engineering and Agriculture, 2(3), 16-21.

[13] Nishimura, J., Saito, T., Yoneyama, H., and Isogai, E. 2012. Biofilm Formation by streptococcus mutans related bacteria. J. Adv. Micro, 2012 (2), 208-215.

[14] Pambayun, R., Gardjito, M., Sudarmadji, S. and Rahayu, K. 2007. Phenolic Conent and Antibacterial Characteristics from Several Types of Gambier Product Extract (Uncaria gambir Roxb). Indonesian Pharmacy Magazine, 18(3), 141-146.

[15] Pambayun, R., Gardjito, M., Sudarmadji, S. and Rahayu, K. 2008. Sensitivity of Gram Positive Bacteria to Catechin Extracted from Gambier (Uncaria gambir). AGRITECH, 28 (4), 175-179.

[16] Parianti, N. and Ariyasa, I. 2015. The Relation between Betel Chewing Activity Habit and Teeth Caries Occurrence for Ederly People in Batu Bulan Kangin Village. Jurnal Virgin Jilid 1, ISSN: 2442-2509, 1(2), 200-208.

[17] Petrina, R., Alimuddin, A. H. and Harlia. 2017. Uji Antioxidant Activity and Toxicity of Areca Nut Skin (Areca catechu L.). ISSN 2303-1077, 6(2), 70-77.

[18] Putri, R.D., Haryadi., Marseno, W.D., dan Cahyanto, N. 2012. Isolasi Dan Karakterisasi Bakteri Asam Laktat Amilolitik Selama Fermentasi Growol, Makanan Tradisional Indonesia. Jurnal Teknologi Pertanian. 13(1), 52-60.

[19] Ryan, L. 2015. Dental Caries: A Current Understanding and Implications. J. Nature. Scie. 1 (1), 1-4.

[20] Saraswati. D. 2011. The Effect of Betel Leaf Extract on Inhibition Powerof Eschericha coli. Jurnal Hearth and Sport, 3(2), 285-362.

[21] Yulineri.T., Kasim. E., and Nurhidayat, N. 2005. Selenium from Seeds and Roots of Areca Nut (Areca catechu L.) Fermented by Consortium of Acetobacter-Saccharomycesas Antiseptic Mouthwash. Journal of Biodiversity, 7(1), 18-20.

[22] Teshome, K., Debela, A. and Garedew, W. 2013. Effect of Drying Temperature Duration on Biochemical Composition and Quality of Black Tea (Camellia sinensis L.) Kuntze at Wush, South Western Ethiopia. Journal of Plant Sciences, 12(6), 235-240. 